\title{
24 HOURS URINARY PROTEIN VERSUS SPOT PROTEIN-CREATININE FOR ASSESSING PROTEINURIA IN PRE-ECLAMPSIA- A COMPARATIVE STUDY
}

\author{
Abiramavalli Kannamani1, Gomathy Thangavelu2, Nabisha Begum Asath ${ }^{3}$ \\ ${ }_{1}^{1}$ Senior Assistant Professor, Institute of Obstetrics and Gynaecology, Egmore, Chennai. \\ ${ }^{2}$ Senior Assistant Professor, Institute of Obstetrics and Gynaecology, Egmore, Chennai. \\ ${ }^{3}$ Assistant Professor, Institute of Obstetrics and Gynaecology, Government Medical College, Pudukottai.
}

\section{ABSTRACT}

\section{BACKGROUND}

The objective of this study is to study the relationship between the 24-hour urinary protein and random urinary spot protein creatinine ratio in pre-eclampsia. This study also aims to determine the ability of random spot protein-creatinine ratio for prediction of significant proteinuria.

\section{MATERIALS AND METHODS}

This was a cross-sectional study conducted on 100 antenatal cases of pre-eclampsia with urinary dipstick value $\geq 1+; 24$-hour urinary sample and a next morning random sample for urinary PCR were collected from all the patients. Amount of proteinuria was estimated by turbidimetric method using sulphosalicylic acid and urinary creatinine was calculated by Jaffe's method; 24-hour urinary protein $\geq 300 \mathrm{mg} / 24$ hours or urinary Protein-Creatinine Ratio $\geq 0.3$ is taken as significant proteinuria. The data thus collected were analysed using appropriate statistical methods.

\section{RESULTS}

$61 \%$ were primi, $39 \%$ were multiparous. Among multiparous, $43.6 \%$ of patients were positive for previous history of pre-eclampsia. All of them had significant urinary PCR. On comparing the 24-hour urinary protein with urinary protein-creatinine ratio, the sensitivity and specificity of urinary PCR is $100 \%$ and $95 \%$, respectively. The positive and negative predictive value is $98.77 \%$ and $100 \%$, respectively. The diagnostic accuracy is $99 \%$. Measure of agreement tests McNemar test $=1.000$, Kappa statistics $p=0.968$ show perfect agreement. Youden Index and Area under the ROC Curve $=1$, which implies $100 \%$ accuracy for PCR significant group with respect to 24-hour urinary protein. From our study, random urinary spot protein-creatinine ratio has a significant linear correlation with 24-hour urinary protein in pre-eclampsia. Since the measure of agreement between these two is perfect, urinary spot protein-creatinine ratio can be used as an excellent alternative for the time consuming 24-hour urinary protein estimation in patients with pre-eclampsia.

\section{CONCLUSION}

Spot protein-creatinine ratio provided a very useful, simple and convenient method for quantitative assessment of proteinuria in pre-eclamptic patients and can replace 24-hour urine collection method in indoor, outpatients and in follow-up clinics as it gives quick and reliable results and avoids the inconvenience and short comings associated with 24-hour urine collection. This study also proves that urinary dipstick alone has a poor sensitivity and specificity in diagnosing proteinuria of pre-eclampsia.

\section{KEYWORDS}

Urine Dipstick, Protein-Creatinine Ratio, 24 Hours Urinary Protein and Pre-eclampsia.

HOW TO CITE THIS ARTICLE: Kannamani A, Thangavelu G, Asath NB. 24 hours urinary protein versus spot protein-creatinine for assessing proteinuria in pre-eclampsia- a comparative study. J. Evolution Med. Dent. Sci. 2017;6(18):1409-1412, DOI: $10.14260 /$ Jemds/2017/308

\section{BACKGROUND}

Hypertensive disorder of pregnancy complicates approximately $15-20 \%$ of pregnancies of which preeclampsia occurs in 2 - 8\%. Pre-eclampsia accounts for 15 $20 \%$ of maternal mortality and a high amount of maternal morbidity.

Financial or Other, Competing Interest: None.

Submission 06-12-2016, Peer Review 19-01-2017,

Acceptance 24-01-2017, Published 02-03-2017.

Corresponding Author:

Dr. Abiramavalli Kannamani,

Plot No. 247,

$1^{\text {st }}$ Main Road,

Eswaran Nagar,

Tiruvallur-602024.

E-mail: rajangamin@yahoo.com

DOI: $10.14260 /$ jemds $/ 2017 / 308$
It is a major pregnancy complication causing preterm birth which is often iatrogenic, intrauterine growth restriction, abruption and intrauterine foetal demise which contribute significantly to perinatal mortality and morbidity.

Estimation of proteinuria is essential for making diagnosis, to assess the severity of disease and also for predicting foetomaternal outcome in pre-eclamptic pregnancies. For estimating the amount of protein in urine collection of 24 hours, urinary sample is taken as gold standard, but it is time consuming, cumbersome and inconvenient.

Routine simple dipstick urine analysis has low sensitivity, high false positive and false negative results. Also, its results are being influenced by maternal hydration status, diurnal variation, presence of infection, exercise, etc.

So, we can use random urinary spot protein-creatinine ratio instead of 24-hour urinary protein to detect significant proteinuria. In this method, urinary protein concentration is 
divided by GFR independent of urinary creatinine concentration. Therefore, it is a useful reference.

\section{MATERIALS AND METHODS}

\section{Study Period}

One year at Institute of Obstetrics and Gynaecology, Egmore, Chennai.

\section{Study Design}

Prospective Study.

In this study, 100 admitted antenatal cases of preeclampsia with urinary dipstick value $\geq 1+$ were selected. General physical and obstetric examination was done for all; 24 hours urinary sample and a next morning random sample for urinary PCR were collected from all the patients. Amount of proteinuria was estimated by turbidimetric method using sulphosalicylic acid and urinary creatinine was calculated by Jaffe's method; 24-hour urinary protein $\geq 300 \mathrm{mg} / 24$-hour or urinary Protein-Creatinine ratio $\geq 0.3$ is taken as significant proteinuria.

\section{The Tests were carried out as follows}

The patients were instructed to collect the 24-hour urine starting from the second urine sample in the morning till the first urine sample next day morning. A sample was collected on the next day for spot protein/creatinine ratio estimation. Amount of proteinuria is estimated by using turbidimetric (Sulphosalicylic acid) method. The results for protein excretion is negative if the 24-hour urinary protein is $<300$ $\mathrm{mg} / 24$ hours, protein-creatinine ratio $<0.3$, clinically significant proteinuria if urinary protein is $\geq 300 \mathrm{mg} / 24$ hours and protein-creatinine ratio $\geq 0.3$.

The ISSHP (International Society for the Study of Hypertension in Pregnancy) defined significant proteinuria as,

1. 24-hour urinary protein $\geq 300 \mathrm{mg} /$ day.

2. Random protein creatinine ratio $\geq 30 \mathrm{mg} / \mathrm{mmol}$.

The data thus collected were analysed using appropriate statistical methods.

\section{Inclusion Criteria}

This study will be carried out on 100 randomly selected, admitted antenatal cases with pre-eclampsia of more than 20 weeks gestation.

\section{Exclusion Criteria}

1. Urinary tract infection.

2. Preexisting renal or vascular disease.

3. Chronic hypertension.

4. Diabetes mellitus.

\section{ANALYSIS AND RESULTS}

Among 100 study patients, 80 had significant proteinuria; $66 \%$ of the patients were in the age group of 20 to 30 years, among them $87.9 \%$ were significant for urinary PCR.

$61 \%$ were primi, $39 \%$ were multiparous. Among multiparous $43.6 \%$ of patients were positive for previous history of pre-eclampsia. All of them had significant urinary PCR
The sensitivity and positive predictive value of dipstick is 67.5\% (95\% CI, 56.64 - 76.76) and 72.97\% (95\% CI, 61.91 81.77) respectively. The diagnostic accuracy is $54 \%$ with respect to 24-hour urinary protein.

The sensitivity and positive predictive value of urinary dipstick is $67.9 \%$ (95\% CI, 57.12 - 77.06) and $74.32 \%$ (95\% CI, 63.35 - 82.9) respectively. The diagnostic accuracy is $55 \%$ with respect to urinary PCR.

On comparing the 24-hour urinary protein with urinary protein-creatinine ratio, the sensitivity and specificity of urinary PCR is $100 \%$ and $95 \%$ respectively. The positive and negative predictive value is $98.77 \%$ and $100 \%$ respectively. The diagnostic accuracy is $99 \%$.

Measure of agreement tests McNemar test $=1.000$, Kappa statistics $\mathrm{p}=0.968$ show perfect agreement. Coefficient of determination (r2) is 0.9571, which infers a very good correlation between 24-hour urinary protein and urinary spot protein-creatinine ratio.

Youden Index and Area under the ROC Curve = 1, which implies $100 \%$ accuracy for PCR significant group with respect to 24-hour urinary protein. In the ROC Curve, the value of 0.3 has maximum sensitivity and specificity.

\begin{tabular}{|c|c|c|c|c|c|}
\hline \multicolumn{6}{|c|}{ Crosstab } \\
\hline & & & \multicolumn{3}{|c|}{$\begin{array}{c}\text { 24-Hour Urinary Protein } \\
\text { Significance }\end{array}$} \\
\hline & & & 0 & 1 & Total \\
\hline \multirow{6}{*}{$\begin{array}{c}\text { Urinary } \\
\text { PCR } \\
\text { Significance }\end{array}$} & \multirow[b]{2}{*}{0} & Count & 19 & 0 & 19 \\
\hline & & $\begin{array}{l}\text { \% of } \\
\text { Total }\end{array}$ & $19.0 \%$ & $.0 \%$ & $19.0 \%$ \\
\hline & \multirow[b]{2}{*}{1} & Count & 1 & 80 & 81 \\
\hline & & $\begin{array}{l}\% \text { of } \\
\text { Total }\end{array}$ & $1.0 \%$ & $80.0 \%$ & $81.0 \%$ \\
\hline & \multirow[b]{2}{*}{ Total } & Count & 20 & 80 & 100 \\
\hline & & $\begin{array}{l}\text { \% of } \\
\text { Total }\end{array}$ & $20.0 \%$ & $80.0 \%$ & $100.0 \%$ \\
\hline
\end{tabular}

McNemar $\mathrm{p}=1.0000$

Kappa Statistics $=0.968$

\begin{tabular}{|c|c|c|}
\hline \multicolumn{3}{|c|}{ Chi-Square Tests } \\
\hline McNemar Test & Value & Exact Sig. (2-Sided) \\
\hline N of Valid Cases & 100 & $1.000 \mathrm{a}$ \\
\hline \multicolumn{3}{|c|}{ Table 2} \\
\hline
\end{tabular}

Binomial distribution used.

\begin{tabular}{|c|c|c|c|c|}
\hline \multicolumn{5}{|c|}{ Symmetric Measures } \\
\hline $\begin{array}{c}\text { Measure of } \\
\text { Agreement }\end{array}$ & Value & $\begin{array}{c}\text { Asymp. } \\
\text { Std. Error }\end{array}$ & Approx. Tb & $\begin{array}{c}\text { Approx. } \\
\text { Sig. }\end{array}$ \\
\hline Kappa & .968 & .032 & 9.686 & .000 \\
\hline $\begin{array}{c}\text { N. of Valid } \\
\text { Cases }\end{array}$ & 100 & & & \\
\hline \multicolumn{5}{|c|}{ Table 3 } \\
\hline
\end{tabular}

- $\quad$ Not assuming the null hypothesis.

- Using the asymptotic standard error assuming the null hypothesis. 


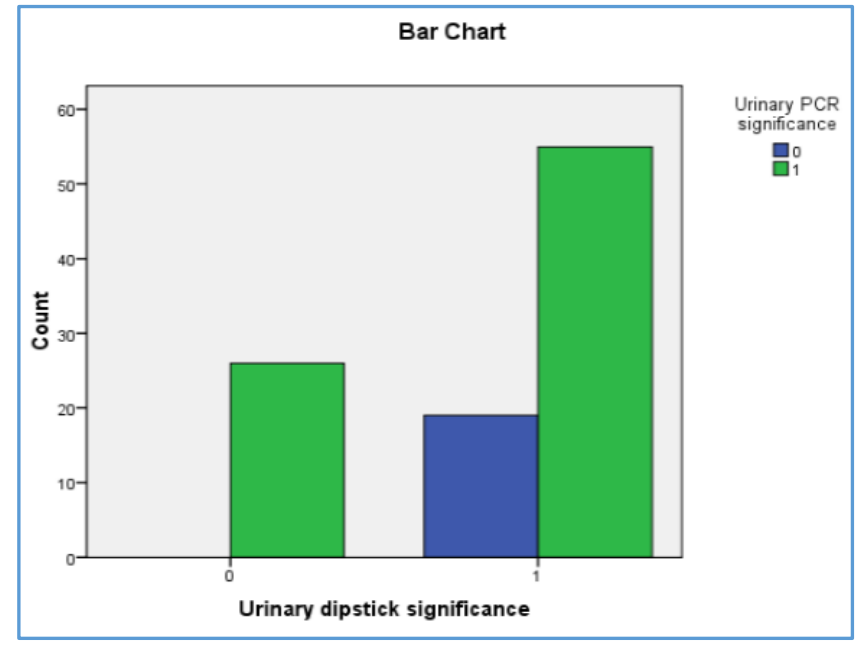

Graph 1. Bar Chart shows the Relationship between Urinary Dipstick and PCR

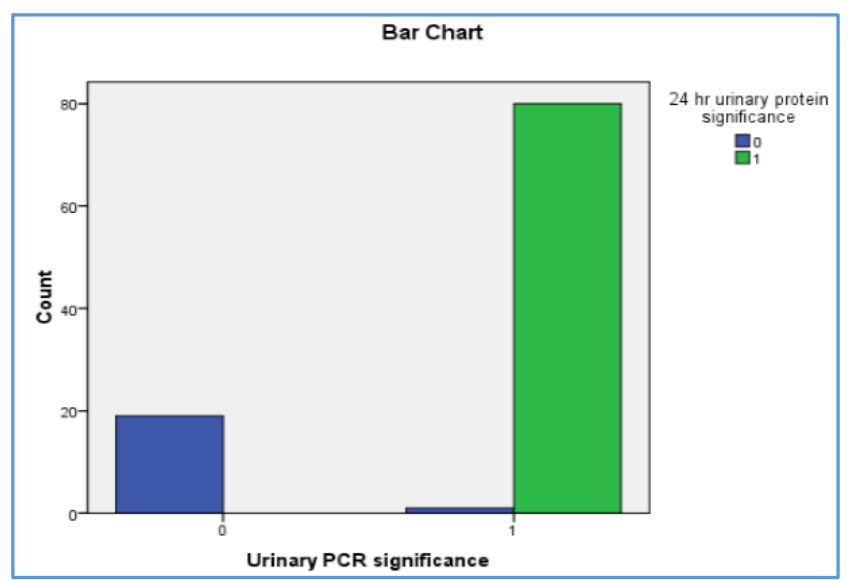

Graph 2. The Bar Chart shows the Relation between Urinary PCR and 24-Hour Urinary Protein

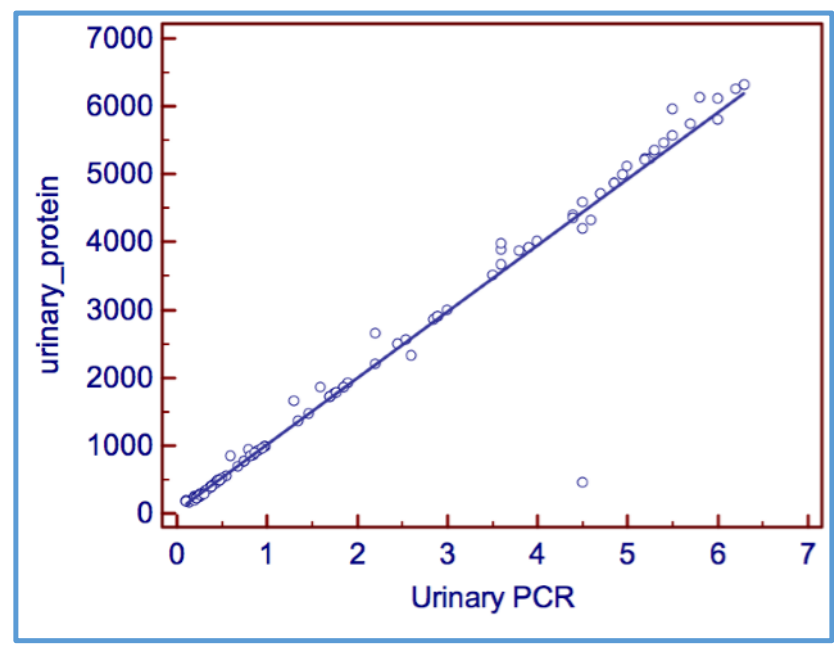

Graph 3. Shows Linear Relationship between 24-Hour Urinary Protein and Spot Urinary Protein-Creatinine Ratio

\section{Correlation}

\begin{tabular}{|c|c|}
\hline Variable Y & Urinary Protein \\
\hline Variable X & $\begin{array}{c}\text { Urinary PCR } \\
\text { Urinary PCR }\end{array}$ \\
\hline \multicolumn{2}{|c|}{ Table 4 } \\
\hline
\end{tabular}

\begin{tabular}{|c|c|}
\hline Sample Size & $\mathbf{1 0 0}$ \\
\hline Correlation coefficient $\mathrm{r}$ & 0.9783 \\
\hline Significance level & $\mathrm{P}<0.0001$ \\
\hline 95\% Confidence interval for $\mathrm{r}$ & 0.9679 to 0.9854 \\
\hline \multicolumn{2}{|c|}{ Table 5 } \\
\hline
\end{tabular}

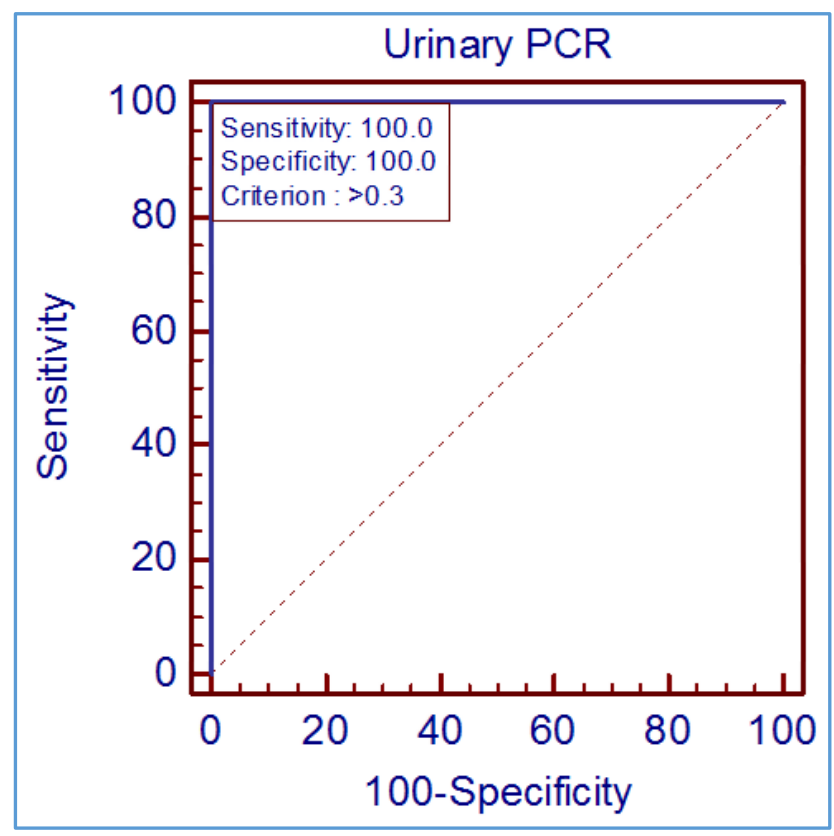

ROC Curve

Graph 4

\begin{tabular}{|c|c|}
\hline Variable & \multicolumn{1}{|c|}{$\begin{array}{c}\text { Urinary PCR } \\
\text { Urinary PCR }\end{array}$} \\
\hline Classification Variable & hr_urinary_protein_significance \\
\hline \multicolumn{2}{|c}{ Table 6 } \\
\hline
\end{tabular}

\begin{tabular}{|c|l|c|}
\hline Sample Size & $\mathbf{1 0 0}$ \\
\hline Positive Group & hr_urinary_protein_significance $=1$ & 80 \\
\hline Negative Group & hr_urinary_protein_significance $=0$ & 20 \\
\hline \multicolumn{2}{|c|}{ Table 7 } \\
\hline
\end{tabular}

\section{DISCUSSION}

Testing for proteinuria is very important in the treatment of pre-eclampsia. ${ }^{1}$ The gold standard testing detection of proteinuria, 24-hour protein collection, is not always performed correctly and can cause delayed diagnosis and the application of treatment. Due to high accuracy, reproducibility and convenience compared with 24 -hour protein collection, the $\mathrm{P} / \mathrm{C}$ ratio in spot urine was developed as an alternative test in the pregnant population.(2) Morales et al(3) reported the potential error in determining protein in a spot urine sample due to daily variation that does not exceed the error in collecting a 24-hour urine sample. Also, until now, the majority of studies evaluating spot urine $\mathrm{P} / \mathrm{C}$ ratio in pregnant women with suspected pre-eclampsia have been found to be closely correlated with the 24-hour urine protein measurement.(4-9) However, in pregnant women, there is no reliable evidence about the optimal cut-off value for spot urine $\mathrm{P} / \mathrm{C}$ ratio for defining pre-eclampsia. The most recent meta-analysis(10) implied that the optimum threshold for $\mathrm{P} / \mathrm{C}$ ratio to define significant proteinuria is between 0.30 and 0.35 regarding sensitivity and specificity values above $75 \%$; when the sensitivity and specificity above $80 \%$ was accepted, there was 
no cut-off found.(10) We found that $\mathrm{P} / \mathrm{C}$ ratio is more sensitive and more specific for the detection of proteinuria $>1 \mathrm{~g} /$ day. From our study, we concluded that random urinary spot protein-creatinine ratio has a significant linear correlation with 24-hour urinary protein in pre-eclampsia. Since the measure of agreement between these two is perfect urinary spot protein-creatinine ratio can be used as an excellent alternative for the time consuming 24-hour urinary protein estimation in patients with pre-eclampsia. Also urinary dipstick alone has a poor sensitivity and specificity in diagnosing proteinuria of pre-eclampsia.

\section{REFERENCES}

[1] ACOG Committee on Obstetric Practice. ACOG practice bulletin. Diagnosis and management of preeclampsia and eclampsia. Number 33, january 2002. American college of obstetricians and gynecologists. Int J Gynaecol Obstet 2002;77(1):67-75.

[2] Durnwald C, Mercer B. A prospective comparison of total protein/creatinine ratio versus24-hour urine protein in women with suspected preeclampsia. Am J Obstet Gynecol 2003;189(3):848-52.

[3] Morales JV, Weber R, Wagner MB, et al. Is morning urinary protein/creatinine ratio a reliable estimator of 24-hour proteinuria in patients with different levels of renal function? J Nephrol 2004;17(5):666-72.

[4] Shahbazian N, Hosseini-Asl F. A comparison of spot urine protein-creatinine ratio with 24-hour urine protein excretion in women with preeclampsia. Iran J Kidney Dis 2008;2(3):127-31.
[5] Wheeler TL, Blackhurst DW, Dellinger EH, et al. Usage of spot urine protein to creatinine ratios in the evaluation of preeclampsia. Am J Obstet Gynecol 2007;196(5):465.e1-4.

[6] Rizk DE, Agarwal MM, Pathan JY, et al. Predicting proteinuria in hypertensive pregnancies with urinary protein-creatinine or calcium-creatinine ratio. J Perinatol 2007;27(5):272-7.

[7] Robert M, Sepandj F, Liston RM, et al. Random proteincreatinine ratio for the quantitation of proteinuria in pregnancy. Obstet Gynecol 1997;90(6):893-5.

[8] Neithardt AB, Dooley SL, Borensztajn J. Prediction of 24-hour protein excretion in pregnancy with a single voided urine protein-to-creatinine ratio. Am J Obstet Gynecol 2002;186(5):883-6.

[9] Eslamian L, Behnam F, Tehrani ZF, et al. Random urine protein creatinine ratio as a preadmission test in hypertensive pregnancies with urinary protein creatinine ratio. Acta Med Iran 2011;49(2):81-4.

[10] Morris RK, Riley RD, Doug M, et al. Diagnostic accuracy of spot urinary protein and albumin to creatinine ratios for detection of significant proteinuria or adverse pregnancy outcome in patients with suspected preeclampsia: systematic review and meta-analysis. BMJ 2012;345:e4342. 